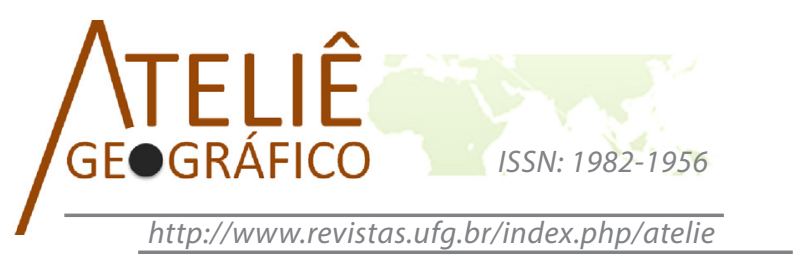

\title{
A indústria de ráfia paranaense: relações entre geoeconomia, geografia industrial e fatores locacionais
}

\author{
The raffia industry in parana: relationships among \\ geo-economics, industrial geography and location factors
}

\section{L'industrie de la raphia au Paraná: les rapports entre la Geoéconomie, la Géographie Industriel et les Facteurs

\author{
de Location
}

\author{
Eliane Horbus \\ Universidade Estadual do Centro-Oeste (PR) \\ eliane.horbus@hotmail.com \\ Pierre Alves Costa \\ Universidade Estadual do Centro-Oeste (PR) \\ alvespierre75@hotmail.com
}

\begin{abstract}
Resumo
Este trabalho versa sobre a indústria de transformação do plástico, no setor de embalagens que atuam na tecelagem e produção de sacarias de ráfia localizadas no Paraná, com enfoque específico na análise do desenvolvimento deste setor no estado. Ademais, discorre sobre os fatores locacionais que influenciaram a instalação das fábricas nas cidades de Guarapuava e Campo Largo, incluindo o levantamento do potencial de geração de empregos, o perfil da mão de obra utilizada e as tecnologias aplicadas no processo fabril. No campo teórico foi abordada a estreita relação entre o estudo das indústrias com a Geografia Econômica e a Geoeconomia. Para atingir os objetivos a que se propõe esta pesquisa, foram realizadas visitas técnicas às fábricas localizadas somente no estado paranaense, utilizando a técnica de verificação in loco com entrevista estruturada, buscando evidenciar as características próprias de cada empresa e seus respectivos fatores locacionais. Por fim, apresenta-se um quadro comparativo sobre o desenvolvimento das três fábricas instaladas no Paraná e a conclusão sobre a influência ou não de fatores locacionais.

Palavras-chave: Geografia Econômica, Geoeconomia, Indústrias de sacaria de ráfia, fatores locacionais.
\end{abstract}




\begin{abstract}
The present paper is a study about the plastic transformation industry, in the packing sector that acts in the textile industry and in the raffia sacks production in Parana, focusing in the analysis of that sector development in the same State. Besides, it discourses about the location factors that influenced the industries construction in Guarapuava and Campo Largo, including the survey about the potential of employment creation, the used labor profile and the technologies applied in the industrial process. In the theoretical field, the slight relation between industry studies with Economics Geography and with Geo-economics was approached. In order to accomplish the objectives of the research, some technical visits to the plants located only in Paraná occurred, using the in loco observation technique with structured interviews, trying to evidence each factory own characteristics and their respective location factors. At last, a comparative table is presented showing the development of the three industries settled in Paraná and the conclusion about the possible influence or not, of the location factors.
\end{abstract}

Keywords: Economics Geography, Geo-economics, raffia sacks industry, location factors.

\begin{abstract}
Résumé
Ce travail examine l'industrie de la transformation des matières plastiques au secteur de l'emballage du tissage et dans la fabrication des sacs en raphia situés au Paraná, avec un accent particulier sur l'analyse du développement de ce secteur dans l'État. En autre, il s'agit des facteurs de localization qui ont influencé l'installation des usines dans les villes de Guarapuava et Campo Largo, en intégrant le soulèvement du potentiel de création d'emplois, le profil de la main-d'ouvre employée, bien que les techonologies appliquées dans le processus de fabrication. En théorie, on aborde le rapport étroit entre l'étude des industries de la (Géographie Économique) et la Géoéconomie. Comme ça, pour atteindre les objectifs auxquels on poursuit cette recherche on a eu des rendez-vous techniques aux usines situées uniquement dans l'État du Paraná, en utilisant la technique de numérisation in loco (sur site) d'entrevue structurée pour essayer de mettre en évidence les caractéristiques de chaque enterprise et leurs facteurs de localisation. Enfin, on présente un tableau comparatif sur le développement des trois usines du Paraná et la conclusion sur les probables influences des facteurs de locasisation.

Mots-clés: Géographie Économique; Géoéconomue; La raphia; Facteurs de Localisation.
\end{abstract}

\title{
Introdução
}

Ao estudar a geografia econômica verifica-se que esta explica momentos históricos da humanidade, como por exemplo, as mudanças ocorridas na divisão social e territorial do trabalho pós Segunda Guerra Mundial, o desmoronamento do bloco soviético, o surgimento dos países de Terceiro Mundo e da China no mercado global, De igual importância são os estudos que se referem à Geoeconomia, que tem uma característica diferente da geografia econômica.

Entendemos como Geografia Econômica a distribuição de diferentes fatores de produção e de riquezas, desde as matérias primas às instalações fabris, dos recursos humanos à macrologística, que inclui meios de transporte, de armazenamento e de redistribuição de 
fluxos de mercadorias. Por outro lado, a Geoeconomia é uma disciplina econômica que, no plano científico, propõe, ou visa propor, as leis que comandam a função dos territórios no sistema de produção, distribuição e exploração das riquezas; no plano normativo viabiliza recomendações para o retrato de políticas públicas pertinentes, citando caso análogo, as políticas regionais, as políticas para as regiões metropolitanas ou as políticas de cluster. Entende-se por cluster, no mundo da indústria, uma concentração de empresas que se comunicam por possuírem características e coabitarem no mesmo local.

No campo acadêmico, a geografia econômica passa a ser reconhecida como a nova geografia, qual contorna conceitos econômicos, confrontando os espaços urbano e agrícola (NUNES, 2000). Na tentativa de ampliar os estudos sobre geografia econômica e geoeconomia, este trabalho contempla a geografia industrial tendo como objeto de estudo a análise do desenvolvimento do setor de sacaria de ráfia no Estado do Paraná.

Entende-se como relevante este estudo, pois as indústrias são o setor econômico de amplo espectro socioeconômico, capazes de mobilizar e catalisar regiões inteiras. É o caso da indústria petroquímica, a qual é conceituada por muitos autores como sendo a indústria que abrange uma maior pauta com outros setores da economia, e cuja produção de petróleo, gás natural e seus derivados a classifica dentre os demais ramos industriais como aquela de maior poder germinativo e de maior relacionamento com os demais setores da vida econômica (PERRONE, 2010). Destaca-se ainda que esta indústria, a qual se deriva o plástico, é o foco deste estudo no que concerne às indústrias de ráfia. ${ }^{1}$

As sacarias de ráfia são fábricas que integram o complexo industrial denominado Polo Petroquímico Brasileiro. Conforme a Associação Brasileira dos Produtores de Fibras Poliolefínicas (2010), no Brasil encontram-se dezenove fábricas que produzem tanto o tecido como a sacaria de ráfia, sendo que no Paraná encontram-se três delas, duas localizadas no município de Guarapuava e uma no município de Campo Largo.

A partir destas considerações iniciais, este estudo se mostra relevante no contexto atual de desenvolvimento regional, visto que ao analisar a evolução do setor de sacaria de ráfia no estado paranaense, pretende-se especificamente, levantar indicadores da geografia econômica e industrial relacionados à capacidade de geração de emprego, potencial produtivo, existência e influência de fatores locacionais. Ainda, este trabalho procura discutir e descrever as fábricas de sacaria de ráfia no Paraná, demonstrando a especificidade de cada uma das empresas e a existência ou não de fatores locacionais específicos que determinaram a localização deste ramo de empresa em duas cidades do Paraná: Campo largo e Guarapuava.

\section{Geografia Econômica e Geoeconomia}

A referência bibliográfica sobre geografia econômica e sua evolução na história do pensamento geográfico, ainda é escassa. Segundo Wooldridg e East (1967), o termo Geografia Econômica foi utilizado pela primeira vez pelo alemão Gotz em 1882, para

1. Sacarias de ráfia são embalagens plásticas de diversos tamanhos, utilizadas para acondicionar diversos tipos de produtos a granel como por exemplo: farelos, rações, cereais, sementes, farinhas entre outros. 
distinguir seus trabalhos de Geografia Comercial. A Geografia Comercial era utilizada apenas como espécie de material de consulta, pois se restringia a afirmações e fatos com dados históricos e estatísticos referentes à produção e trocas de mercadorias.

Os autores Wooldridg e East (1967, p.109) afirmam:

A Geografia Econômica seria a Geografia Comercial, tratada do ponto de vista das relações de causalidade. Seu objetivo seria o estudo científico das áreas do mundo, com respeito à influência direta que exercem sobre a produção de mercadorias. Nesse particular definiu-se ao longo do caminho que muitos geógrafos, especialistas em Geografia Econômica trilharam, buscando verificar acima de tudo, a influência dos fatores de ordem física sobre as ocupações, os produtos, e de modo mais geral, a vida dos povos estabelecidos nas diferentes partes do globo. Trata-se, pois, de uma tarefa eminentemente geográfica e relacionada de maneira direta como o campo da Geografia Geral, possuindo bastante em comum com o mesmo. Procura estabelecer para o mundo, considerado como um todo, a natureza e o fundamento lógico de suas diferenciações regionais. (...)

Segundo Nunes (2000), ao se tomar por base os períodos e as correntes que constituíram a geografia moderna, pode-se dizer que a Geografia Econômica está vinculada à corrente Francesa, que teve como principal expoente Paul Vidal de La Blache (1845 - 1918). Para La Blache (1954), entende-se que os fatos econômicos são uma consequência do humano, ou seja, as atividades econômicas como comércio e circulação são vistos como fatores do desenvolvimento humano. Destaca-se a circulação como fator principal no progresso dos meios de transporte para o desenvolvimento econômico.

Dentre as especializações surge então a Geografia Econômica, que inicialmente ocupava-se em estudar a vida econômica de uma região, analisando os fluxos, o trabalho, a produção, articulando população, comércio, indústria, transportes, entre outros elementos que fazem parte do quadro regional. No início pode-se dizer que a Geografia Econômica preocupava-se com o reconhecimento da vida econômica regional. A partir dos pressupostos de La Blache alguns autores desenvolveram estudos mais específicos nos quais se encontra uma preocupação com as questões econômicas. Um momento em que também pode ser destacada a Geografia Econômica no pensamento Geográfico referese à década de 1950. A partir da Segunda Guerra Mundial o capitalismo sofreu mudanças no que diz respeito à divisão social e territorial do trabalho; isso se refletiu nas ciências, em especial nas humanas, tendo em vista o progresso de seus suportes e a necessidade de se buscar alternativas que respondessem às novas exigências (SANTOS, 1980).

No que se refere à Geografia Econômica brasileira, Silva (1988) comenta que esta se desenvolveu segundo quatro temas que foram sucessivamente se impondo em vista das transformações ocorridas nos últimos trinta anos. Segundo o autor, estes temas seriam:

$>$ Recursos naturais e posteriormente recursos humanos, que se desenvolveram a partir da década de 1940 quando, com o inicio da implantação da indústria de base no Brasil, os problemas da agricultura e pecuária começaram a ganhar dimensões diferentes da perspectiva da industrialização; 
> Produção e circulação, que foram introduzidos na década de 1950, levantando-se a questão da localização de atividades relacionadas ao sistema econômico tendo em vista as variáveis geográficas;

$>$ Desenvolvimento e subdesenvolvimento, surgindo na década de 1960 e início da de 1970, discutindo os problemas anteriores de recursos e de produção e circulação;

> Problemas referentes à organização do espaço, introduzidos na década de 1970 englobando os anteriores, principalmente a teoria da localização que passa a ser vista como parte da problemática regional.

Nunes (2000) destaca que nos fins da década de 1980 e início da de 1990, com as mudanças na economia global nas relações de poder e a chamada crise paradigmática do mundo moderno, a Geografia Econômica passa a se preocupar então com as questões que envolvem o mundo em mutação. Dessa maneira, a partir do novo paradigma tecnoeconômico baseado na informação, surgem novos processos e temas como a reestruturação industrial, acumulação flexível, flexibilização das relações de trabalho, entre outros.

Buscando fazer uma análise mais atualizada da Geografia Econômica, Benko (1996) destaca que a Geografia Econômica contemporânea chama a atenção para assuntos que não dizem respeito apenas ao sistema produtivo em si, mas ao papel de alguns conceitos e questões como modo de regulação, modelo de desenvolvimento, paradigma tecnológico, entre outros para a compreensão da organização territorial da produção contemporânea. Ou seja, não basta apenas localizar a produção, devese explicar o movimento dessa produção e o conjunto de elementos envolvidos que produzem as diferentes configurações espaciais.

Faz-se mister elencar que devido o paradigma da economia industrial não ser mais capaz de explicar a realidade, a Geografia Econômica precisa se fundamentar em outros temas, tornando-se uma Geografia Econômica de múltiplas dimensões considerando quatro níveis: microeconomia de indivíduos e empresas; macroeconomia de estado-nação; a economia do capital global ou mundial (MARTIN, 1996). Portanto, considera-se que a geografia econômica não é mais entendida somente como um estudo da produção, mas sim de fatores como: localização, distribuição e organização espacial das atividades econômicas na Terra, proporcionando o entendimento das relações entre empresa, governo e mercado; nas diferentes escalas espaciais (do local ao global).

Entretanto, ao conceituar a geoeconomia verifica-se que segundo Egler (2008), a Geoeconomia é uma das disciplinas situadas entre a geografia e a economia. Alguns temas como: geografia comercial, geografia econômica, economia geográfica, ciência regional, nova geografia econômica e geoeconomia são alguns elos, ora considerados como parte da geografia, ora como parte da economia. Na verdade, o que mais interessa não é o vínculo com uma ou outra área e sim que a natureza do objeto de estudo, o espaço da produção e reprodução social necessitam de conhecimento compartilhado entre a geografia e economia. No Brasil a Geoeconomia é um termo consagrado, talvez não entre os geógrafos acadêmicos, mas em textos legais como a Constituição Brasileira, na linguagem corriqueira e também entre os economistas. 
Importante salientar que existe uma distinção entre geografia econômica e geoeconomia; segundo Neves (2011), Geografia Econômica é a distribuição de vários fatores de produção e de riquezas, desde as matérias primas às instalações fabris, dos recursos humanos à macrologística, que inclui meios de transporte, de armazenamento e de redistribuição de fluxos de mercadorias. A geoeconomia é uma disciplina econômica que, no plano científico procura determinar as leis que regem o papel dos territórios no sistema de produção, distribuição e exploração das riquezas; no plano normativo fornece indicações para o desenho de políticas públicas adequadas, como por exemplo, as políticas regionais, as políticas para as áreas metropolitanas ou as políticas de cluster. Abordar esses aspectos geoeconômicos implica tratar da globalização. ${ }^{2}$

Pires (2001) aponta que, após um extenso levantamento bibliográfico sobre as principais vertentes teóricas que analisam o processo de globalização, foi identificada a existência de três relevantes correntes:

$>$ Primeira - a globalização como estratégia das empresas globais. Esta corrente foi consolidada por Michael Porter (1993), da Harvard Business School.

Segundo Porter, não são as nações, e sim as empresas globais que definem as estratégias de localização das atividades econômicas nos países. Podese afirmar, com base em tal assertiva, que as empresas globais são os novos sujeitos do processo de localização das atividades econômicas das nações. Para esse autor, as empresas globais buscam componentes e materiais por todo o mundo e localizam suas atividades aproveitando-se dos fatores de baixo custo, formando alianças com empresas em outros países para ter acesso a essas vantagens. (PIRES, 2001, p. 155).

Segundo Porter (1993), o papel dos Estados, neste novo contexto da globalização, seria o de se adaptarem ao novo paradigma organizacional das empresas globais; ocasionando a formação de uma escala de fatores benéficos ao desenvolvimento das vantagens competitivas nacionais. Neste panorama, a globalização insere-se como uma imposição para o desenvolvimento econômico dos países.

$>$ Segunda - a globalização como mundialização do capital. Tem como principal defensor François Chesnais (1996), da Universidade de Paris 13.

Para Chesnais (1996), o vocábulo latino mundialização, livre do viés ideológico inserida na palavra globalização, melhor se adequa para analisar os mecanismos de estruturação e valorização do capital produtivo e financeiro na escala internacional. No período contemporâneo da acumulação capitalista, uma parcela do capital produtivo aparta-se do conjunto do capital e valoriza-se como capital financeiro. Este processo, atualmente comum, vem se constituindo como um empecilho estrutural ao conjunto da reprodução lógica do capitalismo. Ademais, o capital financeiro, formado independente

2. Realizaremos, em seguida, uma breve reflexão sobre a temática da globalização. Para uma análise mais completa ver os autores que serão citados. 
e desconectado do lastro real da produção, manifesta-se como um novo tipo de capital, imaginário e falso.

$>$ Terceira - a globalização como processo histórico antigo. Corrente divulgada por Paul Hirst e Grahame Thompson.

Segundo Hirst (1998), não existe nenhum fato novo em usar o vocábulo globalização para definir o contemporâneo processo aglutinador de crescimento do comércio e do investimento internacionais. Este processo, segundo ele, tem origem em 1870 e não à atualidade.

Não obstante, o contemporâneo fenômeno da globalização, iniciado na década de 1980, detém aspectos distintos dos três períodos de globalização anteriores:

$>\mathrm{O}$ primeiro, designado belle époque, situa-se entre 1870 a 1914, com crescimento médio do comércio e da produção de aproximadamente 3,5\%;

$>$ O segundo, de 1950 a 1973, denominado o grande boom, apresentou aumento médio do comércio e da produção cerca de $9,4 \%$;

> O último período, de 1973 a 1979, caracterizou-se pelas: desregulamentação dos mercados financeiros nacionais, aplicação de taxas de câmbio flutuantes e liberalização generalizada dos movimentos de capitais; com ampliação média do comércio e da produção por volta de $9 \%$.

Ressaltamos que o aspecto primordial do período contemporâneo da globalização é sua expressiva habilidade desestabilizadora e destrutiva da economia mundial. Hirst (1998, p. 120-121) alerta:

O perigo atual é que a crença de que a economia global é ingovernável poderá levar ao fatalismo e à rendição, isto é, a render-se às panaceias preconizadas pelos mercados financeiros internacionais e pelas ricas elites nacionais. $O$ perigo das políticas atuais é que elas favorecem a riqueza nos países desenvolvidos, em detrimento da ampla classe média, e favorecem a Comunidade Européia e um pequeno número de países em desenvolvimento bem sucedidos, em detrimento dos pobres da África, América do Sul e Ásia.

Continuando o debate sobre a globalização, observamos que, conforme o geógrafo britânico Peter Dicken (2010, p. 23), ela é um dos vocábulos mais usados; assim, como é também um dos mais mal empregados e confusos dos dias atuais. "Nos últimos 25 anos, ela se consagrou na imaginação popular, mesmo sendo um conceito cujas raízes remontam pelo menos ao século XIX, principalmente nas ideias de Karl Marx".

Hoje, a "globalização" é a nova ordem econômica, política e cultural. Para Dicken (2010, p. 25):

É um mundo em que estados-nação não são mais atores significativos ou unidades econômicas importantes, e em que as preferências e culturas do consumidor são homogeneizadas e satisfeitas com o fornecimento de produtos globais padronizados, criados por corporações globais sem qualquer fidelidade 
a local ou comunidade. Por conseguinte, a ordem 'global' é considerada a ordem natural, um estado de coisas inevitável, em que o tempo-espaço foi comprimido, o 'fim da geografia' chegou e todo lugar está ficando igual.

Dicken $(2010$, p. 28$)$ continua o debate, dizendo que: “[...] os processos globalizantes se refletem em e são influenciados por diversas geografias, e não por uma única geografia global: uma 'inter-relação local e global mútua, interagindo de todas as formas". É possível identificar tendências (processos localizantes, internacionalizantes, globalizantes, e regionalizantes) que refletem combinações de expansão, integração ou interconexão funcional:

Processos localizantes: atividades econômicas geograficamente concentradas com vários níveis de integração funcional; processos internacionalizantes: expansão geográfica simples de atividades econômicas através das fronteiras nacionais, com baixos níveis de integração funcional; processos globalizantes: ampla expansão geográfica e alto nível de integração funcional; processos regionalizantes: a operação de processos 'globalizantes' em uma escala mais geograficamente limitada (mas supranacional), variando desde a União Europeia, altamente integrada e em expansão, até acordos econômicos regionais muito menores. (DICKEN, 2010, p. 29).

O geógrafo Milton Santos contribui com relevantes reflexões sobre a temática da globalização.

De fato, se desejamos escapar à crença de que esse mundo assim apresentado é verdadeiro, e não queremos admitir a permanência de sua percepção enganosa, devemos considerar a existência de pelo menos três mundos num só. O primeiro seria o mundo tal como nos fazem vê-lo: a globalização como fábula; o segundo seria o mundo tal como ele é: a globalização como perversidade; e o terceiro, o mundo como ele pode ser: uma outra globalização. (SANTOS, 2002, p. 18).

Para este artigo, concentraremos em "uma outra globalização". Santos (2002) defende a ideia que podemos ousar na construção de um outro mundo, mediante um globalização mais humana. As bases materiais do período contemporâneo são, entre outras, a unicidade da técnica, a convergência dos momentos e o conhecimento do planeta.

É nessas bases técnicas que o grande capital se apóia para construir a globalização perversa de que falamos acima. Mas, essas mesmas bases técnicas poderão servir a outros objetivos, se forem postas ao serviço de outros fundamentos sociais e políticos. Parece que as condições históricas do fim do século XX apontavam para esta última possibilidade. Tais novas condições tanto se dão no plano empírico quanto no plano teórico. (SANTOS, 2002, p. 20).

Portanto, para Santos (2002), a globalização é o apogeu do processo de internacionalização do mundo capitalista. Dois componentes são primordiais para a sua compreensão: o estado da política e o estado das técnicas. Não obstante, ressaltamos que a globalização não é apenas a existência desse novo sistema de técnicas. Ela é também, como afirma Santos (2001, p. 24), 
O resultado das ações que asseguram a emergência de um mercado dito global, responsável pelo essencial dos processos políticos atualmente eficazes. Os fatores que contribuem para explicar a arquitetura da globalização atual são: a unicidade da técnica, a convergência dos momentos, a cognoscibilidade do planeta e a existência de um motor único na história, representado pela maisvalia globalizada.

Perante todas as teorias existentes para explicar o processo de globalização, não podemos olvidar o quanto a ciência geográfica é relevante nesse debate. Enfim, como bem reflete Sene (2004, p. 19), o espaço geográfico é uma dimensão primordial da globalização, até porque, apesar de pouco mencionado, o próprio vocábulo "globalização é tributário da geografia, deriva de globo. Desde seu início, redundando na atual etapa da globalização, que a expansão capitalista consiste num processo de incorporação de espaços nos lugares mais recônditos do planeta Terra".

Continuando a reflexão sobre a globalização, lembramos que para Ianni (2001, p. 195), uma das características mais expressivas da globalização do capitalismo é: "as técnicas eletrônicas, compreendendo a microeletrônica, a automação, a robótica e a informática, em suas redes e vias de alcance global, intensificam e generalizam as capacidades dos processos de trabalho e produção".

No mesmo curso da dispersão geográfica das fábricas, usinas, montadores e zonas francas, simultaneamente à nova divisão internacional do trabalho e produção, intensificam-se e generalizam-se as tecnologias destinadas a potenciar a capacidade produtiva de todas as formas sociais de trabalho e produção. (IANNI, 2001, p. 195).

Inserido no debate sobre a globalização, também encontram-se presentes as seguintes temáticas: a modernização do mundo; as economias-mundo; a interdependência das nações; a internacionalização do capital; a aldeia global; entre outros.

Santos (2002, p. 75) afirma que:

Nas condições atuais, um grande complicador vem do fato de que a globalização é frequentemente considerada uma fatalidade, baseada num exagerado encantamento pelas técnicas de ponta e com negligência quanto ao fator nacional, deixando-se de lado o papel do território utilizado pela sociedade como um seu retrato dinâmico.

Terminamos esta breve reflexão concordando com Santos (2002), o qual defende a possibilidade de uma globalização com um caráter mais humanizado, diferente da chamada globalização perversa caracterizada pela pobreza, pelo desemprego crônico, pela fome e o desabrigo que se generalizam por todos os continentes. indústrias.

A seguir, abordaremos as relações entre localização industrial e geografia das 


\section{Geografia Industrial e Localização Industrial}

A indústria representa por excelência o setor criador de novas riquezas e de novos empregos, o que dava a garantia de independência econômica e política: por sua capacidade de produzir diversos efeitos de encadeamento e de múltiplos efeitos induzidos como por sua aptidão em reforçar as polarizações espaciais, a atividade industrial permite atingir o "seio do crescimento autônomo" e um papel determinante no quadro do desenvolvimento econômico regional. Por seu papel nas polarizações espaciais, a indústria influencia diretamente o crescimento urbano, a evolução qualitativa dos conteúdos urbanos, a estruturação das hierarquias urbanas regionais, e não portanto espantoso que ela também tenha se tornado um instrumento maior das políticas de ordenamento do território. (CASTREGHINI; SPOSITO, 2008, p. 24). ${ }^{3}$

Um ponto a ser destacado dentro da Geografia Industrial é em relação à fusão das empresas mais poderosas para enfrentar as concorrentes, o que provocou a formação de dois tipos de concentração: a concentração financeira em que uma empresa ou um grupo econômico passou a deter vários estabelecimentos e a concentração geográfica, uma vez que a indústria, necessitando de uma série de equipamentos e de infraestrutura como bancos, estradas, portos, até mesmo de outras indústrias que fornecessem matéria prima para subsistir e produzir, passou a se localizar em pontos específicos para que essas necessidades fossem plenamente atendidas.

Dessa forma, define-se a Geografia Industrial como o estudo da distribuição geográfica dos complexos industriais, as paisagens por eles geradas e as relações estabelecidas entre os mesmos e os mercados de matéria prima, de mão de obra e de consumo. De uma forma mais ampla, a geografia econômica tem dentre suas preocupações a distribuição espacial das atividades produtivas.

Quando se versa sobre localização industrial, nota-se que Segundo Kon (1994), um dos problemas fundamentais a serem abordados nos estudos relacionados a novos investimentos industriais por uma empresa, refere-se à definição do local em que se instalará o novo estabelecimento. Da mesma forma verificam-se que as escolhas econômicas de uma indústria com relação à ampliação de sua planta ou à construção de novas estão relacionadas não apenas ao preço do produto, à qualidade e à decisão sobre o emprego de fatores, mas também à localização a partir da qual conduzirás suas operações.

Nos esquemas clássicos dos economistas e geógrafos, a questão dos fatores de localização para explicar as repartições territoriais das atividades tem lugar essencial. [...] os esquemas de explicações tradicionais se referem à teoria da localização ideal da fábrica de WEBER e ao papel maior de seu princípio de minimização dos custos de transporte (a localização ideal da indústria corresponde ao ponto do espaço onde se minimiza ao máximo o produto pesado a transportar $\mathrm{x}$ distância de transporte $\mathrm{x}$ tarifa de transporte).

3. As citações desses dois autores são traduções de artigos do geógrafo francês André Fischer. Portanto, representam pensamentos de Fischer. 
A teoria de WEBER permaneceu a principal referência até os anos sessenta. (CASTREGHINI; SPOSITO, 2008, p. 25).

A definição final da localização de uma empresa industrial passa por duas etapas distintas, que observam aspectos da macrolocalização, definindo a região mais ampla, e a microlocalização, definindo as condições físicas do terreno (KON, 1994).

Segundo Mangazol (1985, p. 23) "em escala mundial a distribuição das industrias é resultado de fatores históricos, enquanto, em escala regional, a localização de um estabelecimento é explicada geralmente pela busca do custo mínimo”.

A empresa industrial privada com fins lucrativos determinará sua localização industrial com vistas à máxima rentabilidade do capital a ser investido. Amacrolocalização, neste sentido, definirá a região mais ampla onde deverá ser estabelecida a planta industrial, levando em consideração, além de razões de ordem econômica, também os fatores técnicos. Entre os aspectos econômicos destacam-se acesso a insumos, a mercados, custos de transportes e existência de mão de obra, entre outros. Como fatores técnicos destacam-se as condições climáticas e a facilidade de acesso e de comunicações da região com as demais.

Segundo Kon (1994), entre os fatores econômicos e técnicos que condicionam a escolha da localização industrial podem ser destacados em sequência os mais relevantes, embora não esgotem possibilidade de motivações encontradas:

a) Custos e eficiências dos transportes. A somatória mínima dos custos de transportes de matérias-primas e de produtos acabados é um dos condicionantes básicos da localização industrial. A variável "distância" desempenha um papel fundamental nos estudos locacionais, quando traduzida economicamente em termos de custos e de tempo gasto. Segundo Castreghini; Sposito (2008), o impacto do custo de transporte sobre a localização industrial não é tão determinante quanto outrora fora, mas ainda sim é um quesito levado em questão. Se a região possui uma boa estrutura de transportes (seja ela rodoviária, ferroviária, hidroviária, aérea, marítima ou por condutos), passa a ser uma área muito mais atrativa para as empresas do que outras regiões.

b) Áreas de mercado. O mercado influi diretamente na escolha locacional tendo em vista dois aspectos principais: sua localização e sua dimensão. A localização mais próxima do mercado consumidor conduz a uma maior rentabilidade do empreendimento, principalmente pelos reflexos nos custos de transportes;

c) Disponibilidade e custos da mão de obra. A existência de mão de obra é um fator preponderante na escolha locacional, tanto no que se refere à natureza específica da força de trabalho disponível quanto aos custos incorridos na sua contratação;

d) Custo da terra. Nos casos de plantas industriais, que para sua implantação requerem grandes áreas, o custo da terra pode consistir em um fator decisivo nos cálculos da localização. As áreas situadas mais próximas dos grandes 
centros urbanos apresentam um custo da terra proporcionalmente mais elevado, que se relaciona diretamente à disponibilidade de infraestrutura de serviços complementares. Por outro lado, esse valor também reflete a proximidade de rodovias que constituem grandes eixos de transportes para as áreas situadas na periferia das cidades ou fora dos grandes centros urbanos. Está também incorporada ao preço da terra a disponibilidade de terrenos à venda;

e) Disponibilidade de energia. A existência de energia em suas diversas formas ou mesmo a potencialidade de recursos naturais a serem explorados, bem como o custo unitário, é fator decisivo para a localização de indústrias específicas, em que este elemento pesa consideravelmente no custo final do produto;

f) Suprimentos de matérias primas. As condições de utilização em grande escala ou o caráter perecível ou de fragilidade de certas matérias primas constituem fatores influentes na decisão locacional de indústrias selecionadas;

g) Disponibilidade de água. A disponibilidade e a qualidade da água para uso industrial, nos volumes necessários para determinados tipos de indústrias, constituem fator de crescente importância;

h) Eliminação de resíduos. A industrialização acelerada de uma região implica um nível crescente de poluição ambiental ocasionada pela eliminação de resíduos industriais. A eliminação de resíduos em áreas densamente povoadas ou em áreas ribeirinhas situadas a montante de centros populacionais que se servem d'aqueles cursos d'água, tende a ser controlada através de legislação que implica multas pela sua não observância, ou na exigência de instalação de dispositivos antipoluidores nas plantas como filtros ou outros meios, o que onera os custos de produção;

i) Dispositivos fiscais e financeiros. Em determinadas regiões relativamente atrasadas, a política governamental pode recorrer a incentivos fiscais, subsídios, cessão de terrenos ou ainda a facilidades de acesso ao crédito como fatores de atração do capital privado, no sentido de contrabalancearem as deficiências regionais;

j) Economias de aglomeração. As vantagens representadas por redução nos custos de implantação e operacionalização das plantas industriais, provenientes da existência no local de uma infraestrutura de serviços públicos e privados em forma de transportes, comunicações, suprimento de energia, atividades financeiras, comerciais, de assessoria, de manutenção ou outras, constituem as denominadas economias de aglomeração. Podem-se citar como exemplo, as indústrias de autopeças que se concentram junto às montadoras de veículos;

k) Elementos intangíveis. A existência de determinados elementos ditos intangíveis, em regiões específicas, determina a localização de indústrias cuja demanda é afetada consideravelmente por esses fatores. Trata-se de 
elementos de caráter subjetivo, que influenciam os processos produtivos ou de distribuição do produto, como por exemplo, a tradição ou segredos de família, interferindo na produção de determinados produtos, como alguns bens de luxo, certas indústrias comestíveis ou de bebidas, indústrias artesanais ou produtos de conteúdo artístico com alto valor comercial.

São muitos os elementos que motivam a localização industrial em regiões favorecidas. Dessa forma, a análise da empresa pelo melhor local de implantação do investimento deve contemplar de forma conjunta todos os benefícios e os custos de cada fator responsável pela atração ou repulsão em determinada área potencial. A melhor combinação entre os recursos naturais, humanos e outras forças locacionais existentes para cada produto específico, caracteriza as vantagens de determinada região, ou seja, torna mais adequada a implantação da fábrica comparativamente a outro local.

Segundo Castreghini; Sposito (2008), deve-se considerar também que as exigências de funcionamento das empresas industriais tem passado por significativas mudanças, onde as novas tecnologias assumem uma posição de destaque na transformação do leque de fatores locacionais, tornando o antigo modelo weberiano, de certa forma ultrapassado, visto que o custo de transporte atualmente torna-se secundário frente a fatores como acesso à pesquisa, presença de mão de obra altamente qualificada, além da presença de uma eventual diversidade de serviços à economia.

Ademais, outro aspecto que devemos apontar como um fator locacional são os incentivos fiscais concedidos pelos governos para a implantação de fábricas em seus municípios e estados da federação. Entre eles, destacamos: a) isenção de IPTU4 durante um determinado tempo (normalmente, variando entre 5 a 20 anos); b) concessão de incentivos financeiro-fiscais relacionados aos $\mathrm{ICMS}^{5}$.

Dessa forma, para atrair investimentos e consequentemente mais riqueza e geração de renda para sua região, vários governos promovem incentivos variados para as empresas. Isso vai desde isenção de impostos e infraestrutura até a própria construção das instalações da empresa com dinheiro público.

Vale ressaltar que os incentivos financeiros fiscais relacionados ao ICMS, criados pelos governos na intenção de atrair novos investimentos acabam por gerar a chamada guerra fiscal, que é a disputa, entre cidades e estados, para ver quem oferece melhores incentivos para que as empresas se instalem em seus territórios. Podemos citar um exemplo muito conhecido que é o da montadora Ford, que após uma acirrada disputa entre os estados da Bahia e do Rio Grande do Sul, para ver quem oferecia maiores vantagens fiscais, a empresa decidiu se instalar na Bahia.

A guerra fiscal se trava a revelia da lei complementar 24/75 que veda as concessões de isenção e outros incentivos relacionados ao ICMS, salvo quando previstas em convênios celebrados em reuniões do Conselho de Política Fazendária, que congrega todos os estados e o Distrito Federal. A lei determina

\footnotetext{
4. Imposto Predial e Territorial Urbano.

5. Imposto sobre Circulação de Mercadorias e Serviços.
} 
que a aprovação de concessão de um benefício dependa da decisão unânime dos estados representados e prevê penalidades em caso de inobservância de seus dispositivos. Bastaria o cumprimento dessa lei - nem mesmo o reforço contido nos artigos vetados na LC 87/96 seria necessário para que as guerras fiscais acabassem. (VARSANO, 1997, p. 6).

As desvantagens da guerra fiscal, é que isso faz com que o Brasil em geral, deixe de arrecadar volumosos recursos, em virtude da disputa, sendo que de qualquer forma, ela se instalaria no Brasil. Além disso, quem adquire bens ou serviços de outro estado, quando usufrui de incentivos fiscais no seu estado de origem, pode sofrer sanções, como restrições ao crédito do ICMS.

Ao conceder o incentivo fiscal como eliminação marginal de tributo visando atrair um novo investimento privado que se utilizará de recursos da sociedade é necessário analisar se isto vai atingir benefícios superiores aos quais já existiam, caso contrário, será uma perda para o estado e para o país como um todo (VARSANO, 1997).

Pretendemos com a discussão dos fatores locacionais apresentados até este ponto, ressaltar que estes precisam ser considerados para a escolha do local de implantação da fábrica; respeitando, porém as especificidades de cada tipo de atividade industrial e não os aplicando como modelo único. Importante também é lembrar que após a análise dos fatores que determinam a macrolocalização, é preciso conhecer os fatores que determinam a microlocalização, ou seja, a escolha do terreno dentro da região que oferece as melhores vantagens para aquele tipo específico de produto. Nessa fase predominam os aspectos técnicos relacionados às condições do terreno sem, no entanto, serem descartados os elementos econômicos.

Segundo Kon (1994), a partir da definição da área necessária para implantar determinado processo fabril, são observados os requisitos do terreno baseados nos seguintes elementos:

$>$ Condições de relevo;

$>$ Qualidade do solo;

> Vias de acesso e de comunicação;

$>$ Serviços públicos; (v) Capacidade de infraestrutura;

$>$ Situação legal da propriedade;

$>$ Outros dispositivos legais; e

$>$ Existência de instalações.

A escolha do local será determinada concomitantemente pela melhor área da macro e da microlocalização. Cada tipo de indústria em função de uma estratégia específica de desenvolvimento irá requerer uma escolha entre possibilidades e alternativas de localização. A determinação da alternativa selecionada é efetuada através de uma análise custo/benefício, em que são colocadas em questão conjuntamente todas as vantagens e desvantagens locacionais em relação aos aspectos de macro e microlocalização. $\mathrm{O}$ processo de produção e distribuição da empresa determinará se a escolha da localização é orientada pelos transportes, mão de obra, energia ou outro fator relevante (ALONSO, 
1972). No entanto, ainda que uma indústria seja claramente orientada para um tipo específico de fator, que apresenta peso significativo na composição dos seus custos totais, a existência de outros custos adicionais ou vantagens pode determinar no computo global, uma localização mais afastada daquele condicionante (KON, 1994).

Deve ser ressaltado que toda escolha locacional está permeada de um fator de previsão sobre o desenvolvimento futuro, não apenas das condições econômicas globais de investimento, mas também das expectativas de desenvolvimento futuro da região em questão. Para encerrar a discussão a respeito dos fatores de localização industrial apresenta-se a contribuição de Fischer (2008, p. 48):

Naturalmente a questão dos fatores de localização desemboca na renovação da importância de estratégias espaciais das empresas industriais. Com as novas tecnologias, as estratégias de implantação no espaço se fazem cada vez mais seletivas em função do tipo e do nível tecnológico das atividades e do estabelecimento, porque a disjunção funcional - as deslocalizações periódicas para as zonas menos caras - a pesquisa de ambientes adequados constituem para o futuro importantes elementos na manutenção da produtividade e na competitividade da empresa. [...] Para compreender a importância atual das estratégias espaciais da indústria é necessário, igualmente, levar em conta o fato de que elas podem ser fortemente influenciadas pelas diversas vantagens firmadas com as empresas pelas coletividades locais cujos esforços de desenvolvimento endógeno se traduzem pela vontade de ser o mais atrativo possível.

Enfim, embasados nos aspectos supracitados, este estudo verificará a existência de um fator específico para a escolha da localização ou se um conjunto de fatores foi determinante para a seleção do sítio das empresas de ráfia presentes no Paraná.

\section{A Indústria de Ráfia ${ }^{6}$ : brasileira e paranaense}

Os produtos de material plástico têm ocupado um espaço cada vez maior, lembrando que as primeiras embalagens de alimentos utilizadas eram garrafas de vidro, barricas de madeira, caixas de papelão, sacos a granel. Só em 1960 o plástico começou a adquirir notoriedade com o aumento da oferta de resina e o desenvolvimento da petroquímica nacional. Atualmente os produtos plásticos são cada vez mais elaborados, e considerados como essências à vida moderna (LIMBERGER, 2010). Na figura 1 pode-se observar a distribuição geográfica das fábricas produtoras de plásticos no país. Percebe-se que a maior concentração delas está no estado de São Paulo (46,77\%), seguido pelo Rio Grande do Sul (12,82\%), Santa Catarina (7,77\%) e Paraná (7,72\%); e, que os três estados do Sul têm uma representatividade significativa neste setor, visto que junto somam $27,18 \%$ da produção em todo o país. Ou seja, a indústria de plástico nacional concentra-se na chamada Região Concentrada (SANTOS; SILVEIRA, 2001),

6. Indústria de Ráfia é responsável por transformar o polipropileno (resina termoplástica) em fitas planas com largura entre $3 \mathrm{~mm}$ e $6 \mathrm{~mm}$. Essas fitas planas passam pela tecelagem transformando-as em um tecido único que será utilizado para a confecção dos sacos de ráfia. 
que abrange as regiões Sudeste e Sul. Esta região também concentra a maioria dos outros setores industriais presentes no território brasileiro.

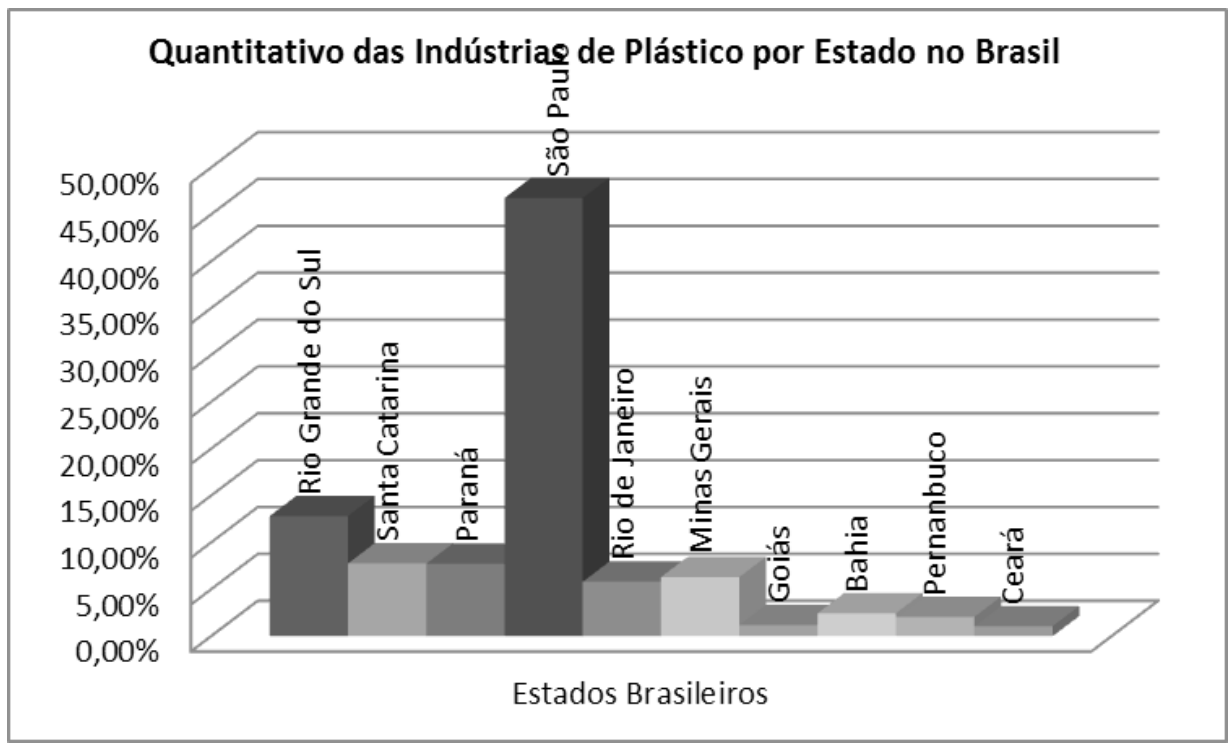

Figura 1. Quantitativo de Indústrias de Plástico no Brasil - Estados da Federação - 2007. ${ }^{7}$ Fonte: ABIPLAST (2007). Elaborado por HORBUS (2011).

No Paraná estão localizadas 08 fábricas que trabalham com a ráfia, porém apenas três dessas empresas possuem o processo completo, ou seja, fazem a extrusão do polipropileno, fazem a fita de ráfia, tecem a fita formando um tecido e por fim confeccionam a sacaria. As demais se dividem em atividades como: somente produzir o tecido de ráfia; produzir somente a sacaria de ráfia a partir do tecido já pronto.

Segundo Holzschuh et al (2008), a ráfia tem como matéria prima o Polipropileno, um material que teve sua introdução no mercado mundial em 1954 e tornou-se uma das mais importantes resinas termoplásticas da atualidade, ocupando o terceiro lugar entre os mais vendidos no mundo. É necessário destacar que o plástico foi criado à aproximadamente meio século causando uma revolução na vida moderna. Tem em sua trajetória o registro de uma evolução tecnológica, muito rápida, delineada pela criação e transformação do material, possibilitando aplicação em grande escala e assim abrangendo diferentes áreas industriais e de consumo (HOTEL NEWS, 2009).

A embalagem de ráfia, um tipo de embalagem plástica, utilizadas para o empacotamento de diversos produtos da economia brasileira. Tem vantagem o fato de poderem ser reutilizadas, ou seja, após o uso não geram lixo, podendo ser reaproveitadas para outros fins, como por exemplo: ensacar sementes para armazéns, insumos, entre

7. Ressalta-se que os últimos dados encontrados em relação ao quantitativo de indústrias de plástico no Brasil foram em 2007, os quais não sofreram alterações até a data atual. 
outras aplicações. Sua principal característica é a resistência e durabilidade comparada a outras embalagens.

\section{O desenvolvimento das fábricas de ráfia no Paraná}

Para conhecer e estudar o desenvolvimento e os motivos que levaram as fábricas de sacaria de ráfia a se instalarem no Paraná realizou-se visita técnica a cada uma das fábricas, utilizando como instrumento de pesquisa a entrevista estruturada. Serão apresentados os dados coletados em cada fábrica para, na sequência se elaborar um comparativo entre as empresas pesquisadas e se demonstrar os fatores locacionais determinantes para a instalação das mesmas.

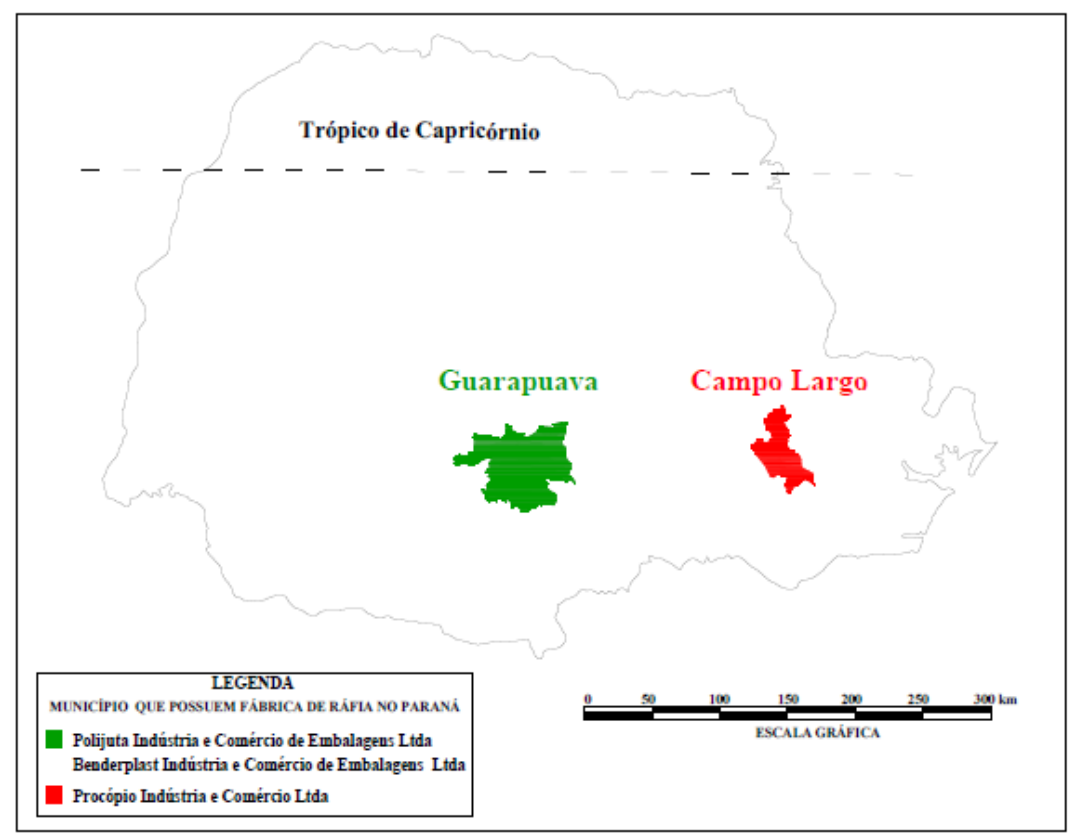

Figura 2. Mapa com a localização das fábricas de Ráfia no Paraná (2007). Fonte: ABIPLAST. Elaborado pela empresa Guarageo (2015).

\section{Procópio Indústria de Sacaria Limitada}

Situada na cidade de Campo Largo ${ }^{8}$, a empresa Procópio, tinha como atividade principal realizar o corte e a costura de embalagens de ráfia (embalagem à base de polipropileno), que eram adquiridas em forma de bobinas e transformadas em sacos

8. Localizado no Aglomerado Metropolitano de Curitiba (AMC). O AMC abrange 12 municípios: Curitiba, Almirante Tamandaré, Araucária, Campina Grande do Sul, Campo Largo, Campo Magro, Colombo, Fazenda Rio Grande, Pinhais, Piraquara, Quatro Barras e São João dos Pinhais. Ressaltamos que esses municípios se 
para acondicionamento de grãos e suplemento mineral, para atendimento do mercado agropecuário. A empresa Procópio tornou-se um Grupo com a abertura de mais filiais, conforme apresentado no quadro 1.

Quadro 1. Empresas afiliadas que formam a empresa Procópio que se tornou um Grupo

\begin{tabular}{|l|l|l|}
\hline Empresa & Ramo de Atuação & Município \\
\hline Procópio Embalagens Ltda. & $\begin{array}{l}\text { Responsável pela confecção de telas para } \\
\text { acondicionamento de batatas. }\end{array}$ & Curitiba - PR \\
\hline Polirafia Embalagens Ltda. & $\begin{array}{l}\text { Responsável pela continuação da } \\
\text { industrialização e comercialização da juta } \\
\text { e costura de telas vazadas (batata, repolho, } \\
\text { cebola, laranja, limão, etc.). }\end{array}$ & Campo Largo - PR \\
\hline $\begin{array}{l}\text { Alçabras Indústria e } \\
\text { Comércio Ltda. }\end{array}$ & $\begin{array}{l}\text { Responsável pela confecção de alças de } \\
\text { alta resistência, utilizadas na montagem } \\
\text { dos contentores flexíveis. }\end{array}$ & $\begin{array}{l}\text { Curitiba - PR } \\
\text { Bairro Industrial }\end{array}$ \\
\hline $\begin{array}{l}\text { Procbag Indústria e } \\
\text { Comércio de Big Bag Ltda. }\end{array}$ & $\begin{array}{l}\text { Responsável pela montagem (corte e } \\
\text { costura) dos contentores flexíveis. }\end{array}$ & Araucária - PR \\
\hline
\end{tabular}

Fonte: Informações colhidas no trabalho de campo realizado em janeiro de 2011.

A partir dos dados coletados por meio de entrevista durante a visita técnica à empresa, verificou-se que a empresa Procópio foi criada com capital próprio dos sócios fundadores e também através de empréstimos bancários, sendo $100 \%$ capital privado nacional. Possui uma área construída de $23.000 \mathrm{~m} 2$ (vinte e três mil metros quadrados) e faz a extrusão de 1500 (mil e quinhentos) toneladas/mês de polipropileno, que são transformados em fitas de ráfia e posteriormente em sacaria.

Apesar dos dirigentes da empresa Procópio afirmarem que, para a decisão de fazer uma fusão entre a matriz e a filial e passar a operar somente em Campo Largo, não levaram em consideração nenhum dos fatores locacionais citados anteriormente, para nós pesquisadores proporcionou uma visão contrária visto que:

a. A decisão por fixar a atividade da empresa Procópio apenas em Campo Largo ocorreu em função de que a filial da empresa já estava instalada e operando nesta cidade; verificou-se, portanto, que seria mais oportuno fazer uma fusão da filial com a matriz que localizava-se em Curitiba, visto que a estrutura física do local onde estava instalada a filial há 4 anos, atendia as necessidades da empresa e ainda possibilitava ampliação.

b. Ainda, um dos fatores levados em consideração foi a valorização do solo urbano de Curitiba, que é bem maior do que em Campo Largo, fato ocorrido a partir da segunda metade dos anos 1980.

c. Outro fator a se considerar foi o fato de que os proprietários que residiam na cidade de Curitiba a aproximadamente $30 \mathrm{~km}$ de Campo Largo não

destacam dentro da Região Metropolitana de Curitiba (RMC) por possuírem um maior dinamismo econômico e a concentração da população. Para uma análise mais completa ver Firkowski (2009); Moura (2009; 2012). 
necessitariam transferir a residência, visto que a distância entre as duas cidades permite deslocamento diário.

d. Apesar da área de manancial que impede em parte a expansão da estrutura física da fábrica, a empresa declara que está satisfeita, não pretendendo mudar de local e que continua ampliando as instalações de acordo com o que é permitido pela legislação ambiental.

Dessa forma o que se percebe é que os fatores locacionais podem não terem sidos considerados no momento da decisão de operar somente em Campo Largo, porém eles estão presentes e proporcionam ainda uma possibilidade de expansão física, o que não seria possível na cidade de Curitiba.

Quanto aos produtos produzidos pela empresa são embalagens têxteis e sintéticas, ou seja, a sacaria. A matéria prima utilizada é o polipropileno e o polietileno proveniente de um único fornecedor em nível nacional, que é a empresa Brasken ${ }^{9}$, dessa forma independentemente do local de instalação da empresa Procópio no estado do Paraná, ela estaria distante do fornecedor.

No quadro 2 são detalhados demais fatores que serão utilizados na análise da influência dos fatores locacionais na escolha do local de instalação da empresa Procópio.

\section{Empresa Polijuta Indústria e Comércio de Embalagens Ltda}

A empresa Polijuta situa-se em Guarapuava. Atingiu seu desempenho total em março de 1992, quando implantou o processo completo, ou seja, a fiação, tecelagem, impressão e acabamento, dominando o processo produtivo com capacidade para produzir 3.000.000 (três milhões) unidades/mês.

De acordo com os dados levantados durante a pesquisa verificou-se que a empresa Polijuta surgiu a partir de um grupo que buscava alternativas para estabelecer um novo empreendimento; este deveria ser instalado na mesma cidade onde residiam. Dessa forma, conclui-se que o local foi escolhido para atender as necessidades pessoais e não por influências de mercado. Há que se destacar, porém, que Guarapuava é uma cidade média do Paraná e que apresentava, na época, boa infraestrutura para sediar empresas industriais, como terrenos amplos, energia, água, telefonia entre outros. Quanto à localização, Guarapuava está no centro-sul do estado do Paraná, sendo servida por estradas federais e estaduais, as quais ligam a cidade a outras regiões do Paraná e também a outros estados.

A empresa foi criada com capital próprio dos sócios proprietários e utilizandose de financiamentos do Banco Regional de Desenvolvimento do Extremo Sul (BRDE) para aquisição de algumas máquinas, sendo 100\% capital privado nacional. A empresa recebeu um único incentivo do município, sendo um terreno de $5.000 \mathrm{~m} 2$ (cinco mil metros quadrados) em uma área industrial da cidade para o início das atividades da fábrica. Mais informações serão apresentadas no quadro 2.

9. Brasken fornecedora do polipropoileno fica localizada nos estados da Bahia, Rio Grande do Sul e São Paulo 
Quadro 2. Resumo referencial das empresas de sacaria de ráfia do Paraná - 2011.

\begin{tabular}{|c|c|c|c|}
\hline $\begin{array}{l}\text { Aspectos } \\
\text { Analisados }\end{array}$ & Empresa Procópio & Empresa Polijuta & Empresa Benderplast \\
\hline Fundação (ano) & 1986 & 1990 & 2004 \\
\hline Município & Campo Largo* & Guarapuava & Guarapuava \\
\hline $\begin{array}{l}\text { Localização no } \\
\text { estado }\end{array}$ & $\begin{array}{l}\text { Aglomerado Metropolitano de } \\
\text { Curitiba }\end{array}$ & Centro-Sul & Centro-Sul \\
\hline Produção (ton/mês) & 1500 & 700 & 1100 \\
\hline $\begin{array}{l}\text { Sistema de } \\
\text { produção }\end{array}$ & $\begin{array}{l}\text { Just in time e técnicas fordistas e } \\
\text { pós-fordistas }\end{array}$ & $\begin{array}{l}\text { Just in time e } \\
\text { técnicas fordistas e } \\
\text { pós-fordistas }\end{array}$ & $\begin{array}{l}\text { Just in time e técnicas } \\
\text { fordistas e pós-fordistas }\end{array}$ \\
\hline $\begin{array}{l}\text { Origem do } \\
\text { maquinário }\end{array}$ & $\begin{array}{l}\text { Maior parte do maquinário é } \\
\text { importado normalmente da Europa }\end{array}$ & $\begin{array}{l}\text { Maior parte } \\
\text { do maquinário } \\
\text { é importado } \\
\text { normalmente da } \\
\text { Europa }\end{array}$ & $\begin{array}{l}\text { Maior parte do } \\
\text { maquinário é importado } \\
\text { normalmente da Europa }\end{array}$ \\
\hline Área construída & $23.000 \mathrm{~m}^{2}$ & $10.000 \mathrm{~m}^{2}$ & $10.000 \mathrm{~m}^{2}$ \\
\hline $\mathrm{N}^{o}$ de funcionários & 603 & 361 & 394 \\
\hline $\begin{array}{l}\text { Ocupação } \\
\text { funcionários }\end{array}$ & $\begin{array}{l}\text { 552 Produção } \\
51 \text { Administrativo }\end{array}$ & $\begin{array}{l}\text { 454 Produção } \\
35 \text { Administrativo }\end{array}$ & $\begin{array}{l}362 \text { Produção } \\
29 \text { Administrativo }\end{array}$ \\
\hline \multirow{5}{*}{$\begin{array}{l}\text { Qualificação da } \\
\text { mão de obra }\end{array}$} & 26 Técnicos & 03 técnicos & 22 Técnicos \\
\hline & 439 Ens. Fundam. & 212Ens. Fundam & 215 Ens. Fundam \\
\hline & 108 Ens. Médio & 245 Ens. Médio & 154 Ens. Médio \\
\hline & 24Ens. Superior & 29 Ens. Superior & 03 Ens. Superior \\
\hline & 6 Especialização & 5 especialização & \\
\hline $\begin{array}{l}\text { Procedência da } \\
\text { Mão de obra }\end{array}$ & $\begin{array}{l}\text { Aglomerado metropolitano de } \\
\text { Curitiba }\end{array}$ & Guarapuava & Guarapuava \\
\hline Energia e água & Não influenciaram & Não influenciaram & Não influenciaram \\
\hline Transporte & Terceirizado & frota própria & frota própria \\
\hline Preço do terreno, & Não influenciou & $\begin{array}{l}\text { Ganhou da } \\
\text { Prefeitura Municipal }\end{array}$ & $\begin{array}{l}\text { Recebeu como parte } \\
\text { de pagamento de uma } \\
\text { negociação. }\end{array}$ \\
\hline $\begin{array}{l}\text { Mercado } \\
\text { Consumidor }\end{array}$ & $\begin{array}{l}\text { Minas Gerais, São Paulo, Rio } \\
\text { Grande do Sul e Bahia } \\
\text { Mercosul e Europa }\end{array}$ & $\begin{array}{l}\text { Goiás, Rio Grande } \\
\text { do Sul,São Paulo e } \\
\text { Paraná }\end{array}$ & $\begin{array}{l}\text { São Paulo,Goiás, Minas } \\
\text { Gerais, Santa Catarina e } \\
\text {, Rio Grande do Sul, }\end{array}$ \\
\hline Matéria Prima & Braskem & Braskem & Braskem \\
\hline Incentivos Fiscais & Não possui & Não possui & Não possui \\
\hline Qualidade de vida & Não avaliado & Não avaliado & Não avaliado \\
\hline $\begin{array}{l}\text { Pesquisa/ } \\
\text { universidade }\end{array}$ & Não utilizam & Não utilizam & Não utilizam \\
\hline $\begin{array}{l}\text { Motivo da escolha } \\
\text { do local }\end{array}$ & $\begin{array}{l}\text { União das atividades da matriz com } \\
\text { a filial e contar com um espaço } \\
\text { maior para ampliação das estruturas } \\
\text { e por comodidade dos empresários } \\
\text { que não precisaram deixar o local } \\
\text { onde residiam }\end{array}$ & $\begin{array}{l}\text { Empresários } \\
\text { optaram por investir } \\
\text { na cidade onde } \\
\text { residiam. }\end{array}$ & $\begin{array}{l}\text { Empresário optou por } \\
\text { permanecer na mesma } \\
\text { cidade e por possuir a } \\
\text { área para instalação da } \\
\text { empresa. }\end{array}$ \\
\hline
\end{tabular}

* Esta empresa instalou-se inicialmente na cidade de Curitiba, no ano de 1968; onde, atualmente localiza-se a empresa Havan, na saída de Curitiba em direção à Ponta Grossa (na BR-277). Em 1990 ocorreu a fusão entre a matriz que estava instalada em Curitiba/PR e a filial que estava instalada em Campo Largo/PR. 


\section{Empresa Benderplast Indústria e Comércio de Embalagens Ltda}

A Empresa Benderplast foi fundada em 04 de dezembro de 2004, por um empresário do ramo de embalagens de polipropileno, tecidos e sacarias de ráfias, com conhecimento neste segmento desde 1990. O proprietário da Benderplast era um dos sócios da empresa Polijuta e após abertura da sociedade o mesmo fundou a empresa Benderplast ao lado da empresa Polijuta. O parque industrial da Brenderplast possui mais de $10.000 \mathrm{~m} 2$ de área construída com máquinas de alta tecnologia, aliado, aos seus mais de 380 colaboradores constantemente treinados, tem capacidade de produção em torno de 1.100 toneladas/mês, entre fios, tecidos e sacaria de ráfia (Polipropileno).

Assim como declarado pelas empresas Procópio e Polijuta, a empresa Benderplast também afirma que nenhum dos fatores locacionais já citados anteriormente influenciaram na decisão de escolha do local de implantação, porém há que se destacar novamente, que Guarapuava é uma cidade média que possui a maior parte dos fatores locacionais e mesmo não sendo considerados pela empresa como fatores de influência na escolha da localização, esta é uma informação a ser contabilizada para efeito de análise.

Durante o período de 2004 a 2011 a empresa não recebeu nenhum tipo de incentivo fiscal; porém, a mesma tem tentado junto a Prefeitura Municipal a doação de um terreno de divisa com a sua empresa com o objetivo de ampliar as instalações. Para o período da realização desta pesquisa, a solução utilizada por esta empresa para ampliar as instalações e atender a crescente demanda pelos produtos foi alugar dois barracões que ficam localizados em frente e ao lado da fábrica. Para a instalação da empresa foi utilizado capital próprio. No entanto, após o conhecimento de uma pesquisa realizada na área do agronegócio, a qual demonstrou uma excelente perspectiva, a empresa em questão decidiu investir por meio de financiamento bancário, em mais maquinário, prevendo que aumentaria a demanda por sacaria de ráfia utilizada para o empacotamento de produtos agrícolas.

\section{Análise comparativa das empresas de sacaria de ráfia do Paraná}

Após o levantamento de dados realizado nas três fábricas de sacaria de ráfia localizadas no Paraná, chegou-se à conclusão de que quanto a alguns aspectos as empresas possuem algumas semelhanças e também algumas diferenças.

Fonte: Dados coletados durante o trabalho de campo realizado no período de janeiro a junho de 2011.

Quanto à escolha do local, apesar de nenhuma das três fábricas declararem que algum fator locacional influenciou na escolha da localização ou que representou um ganho estratégico na instalação, é necessário destacar que a empresa Procópio mudou a instalação fabril de Curitiba para Campo Largo em um período em que os terrenos em Curitiba sofreram uma valorização considerável em relação aos preços de terreno praticados em Campo Largo. Outra consideração a ser feita é que a empresa Polijuta ganhou da prefeitura municipal um terreno, fato que pode ser considerado como um incentivo à implantação da empresa. Há que se considerar ainda que o proprietário 
da empresa Benderplast optou por instalar a sua fábrica em Guarapuava, por possuir experiência no ramo há 14 anos e por ter recebido como forma de pagamento ao sair da sociedade da empresa Polijuta um terreno, o que pode ser considerado um fator relevante para a instalação da empresa Benderplast.

Das três empresas pesquisadas nenhuma recebeu algum tipo de incentivo fiscal, não possuem benefícios relacionados à energia e água, e a maioria da mão de obra que atua na produção não necessita de uma formação específica, o que pode ser comprovado com os dados apresentados, que demonstram que aproximadamente $90 \%$ a $93 \%$ dos funcionários das três empresas analisadas possuem formação entre o ensino fundamental e médio e ocupam cargos na área da produção. Outro fator relacionado com a mão de obra, é que os funcionários das empresas são provenientes da mesma cidade onde a empresa está localizada.

Quanto à infraestrutura de transportes, as duas fábricas que estão localizadas em Guarapuava, optaram por investir em frota própria para maior comodidade da empresa e dos clientes. O maquinário utilizado pelas três empresas paranaenses envolve tanto equipamentos manuais e antigos, como os teares, por exemplo, quanto equipamentos importados computadorizados e altamente sofisticados.

O mercado consumidor é outro fator muito semelhante entre as empresas, pois possuem clientes praticamente nos mesmos outros estados brasileiros, com exceção da $\mathrm{B}$ que tem o maior número de clientes localizados no estado do Paraná. As diferenças encontradas entre as três empresas analisadas consistem no tamanho da área construída, número de funcionários, tempo de existência, e quantidade produzida.

Quanto ao tamanho das instalações, concluiu-se que a empresa Procópio tem o dobro da área construída tanto da empresa Polijuta quanto da Benderplast. Porém, a empresa Benderplast, com aproximadamente metade da estrutura física da empresa Procópio e dependendo ainda de barracões alugados próximos da empresa, está fazendo a extrusão de apenas 400 (quatrocentas) toneladas/mês a menos que a empresa Procópio.

Percebe-se também que a empresa Benderplast está no mercado há apenas 9 anos, contra 43 anos da empresa Procópio e 21 anos da empresa Polijuta, assim mesmo está produzindo quase que a mesma quantidade de toneladas da empresa Procópio e que ultrapassou em 400 toneladas mês a empresa Polijuta.

O número de funcionários é algo que merece destaque, pois se pode verificar que a empresa Berderplast tem 209 (duzentos e nove) funcionários a menos que a empresa Procópio. Porém, a diferença da quantidade produzida é de apenas 400 (quatrocentos) toneladas. Analisando esse mesmo aspecto entre as empresas Polijuta e Benderplast, percebe-se que a empresa Benderplast tem apenas 33 (trinta e três) funcionários a mais que a empresa Polijuta, e tem uma produção superior em 600 (seiscentas) toneladas. Ressaltamos que a empresa Benderplast, por ter sido a última das três empresas do Paraná a ser instalada (2004), detém um maquinário mais recente. Portanto, mais moderno, com maior índice de tecnologia embargado; com isso, diminuindo o tempo de produção; e, consequentemente aumentando a produtividade. 
Os dados obtidos através da pesquisa realizada nas três fábricas de Sacaria de Ráfia do Paraná possibilitam chegar à conclusão de que os fatores de localização entendidos como clássicos, ou seja, mão de obra, água e energia, transportes, incentivos fiscais, entre outros, não tiveram forte influência na escolha do local para a instalação de nenhuma das empresas. Segundo informações obtidas nas empresas, o fator decisivo para a instalação das fábricas onde estão foi por poder permanecer no local onde os proprietários residiam.

Pode-se dizer que a evolução das três empresas analisadas está principalmente relacionada à possibilidade de divulgação de seus produtos para todo o Brasil, utilizando a ferramenta da internet e reforçada pelo atendimento do departamento comercial instalado em cada fábrica, e com o investimento em maquinário moderno que permite o aumento da produção e o modelo de gestão próprio de cada empresa.

Na prática, os fatores locacionais foram importantes para a implantação das três fábricas: $\mathrm{AMC}^{10}$ (concentra infraestrutura e população; portanto, mão-de-obra disponível; rodovias; preço do terreno mais barato que na capital - Curitiba). Guarapuava é uma cidade média/polo regional que também apresenta uma infraestrutura razoável. Como as duas fábricas estão localizadas fora da área urbana do município, os terrenos também apresentam preços mais baratos.

\section{Conclusão}

Constatou-se que os temas Geografia Econômica e Geoeconomia, têm ocasionado discussões e análises sobre o que, de fato, cada um desses termos representa. Verificouse também que a Geografia e a Economia percorreram, durante um período de tempo, caminhos diferentes, onde a primeira ocupava-se em descrever os espaços e a segunda, questões como oferta, procura e fatores de produção. O termo Geografia Econômica ganhou, todavia, cada vez mais adeptos e manteve-se como a principal designação da subdisciplina nascida da união entre as duas áreas científicas, apesar de cada vez mais se ouvir falar em Geoeconomia, vocábulo formado por analogia ao termo Geopolítica.

Como foram abordados os aspectos geoeconômicos, isto implicou em tratar da globalização. O termo globalização tem sido muito difundido e usado de forma indiscriminada, assim torna-se um termo polêmico; porém, ao se utilizar um enfoque de economia global, considera-se que existem outras formas de globalização, como a política, cultural e social, já que a economia não é uma entidade isolada e está profundamente incorporada aos demais processos (políticos, sociais e culturais).

Abordaram-se questões relacionadas à localização industrial, visto que este tema tem uma relação direta com o objeto de estudo dessa pesquisa. Segundo Kon (1994), um dos problemas fundamentais a serem abordados nos estudos relacionados a novos investimentos industriais por uma empresa refere-se à definição do local em que se instalará o novo estabelecimento. As escolhas econômicas de uma indústria com relação à ampliação de sua planta ou a construção de novas unidades estão relacionadas

10. AMC - Aglomerado Metropolitano de Curitiba. 
não apenas ao preço do produto, qualidade e decisão sobre o emprego de fatores, mas também a localização a partir da qual conduzirás suas operações.

A teoria clássica da localização industrial aponta como fatores locacionais o custo com transporte, disponibilidade de água e energia, disponibilidade de mão de obra, proximidade com o mercado consumidor, preço do terreno, suprimento de matéria prima, além de incentivos fiscais e financeiros. Todos estes fatores foram detalhadamente apresentados e definidos no texto, porém fez-se necessário uma abordagem mais contemporânea acerca do assunto e para isso contou-se com as contribuições de André Fischer (2008), geógrafo francês, o qual tem um vasto conhecimento na área da Geografia Econômica. Segundo Fischer (2008), deve-se considerar que as exigências de funcionamento das empresas industriais têm passado por significativas mudanças, onde as novas tecnologias assumem uma posição de destaque na transformação do leque de fatores locacionais, tornando o antigo modelo weberiano, de certa forma ultrapassado, visto que o custo de transporte atualmente torna-se secundário frente a fatores como acesso a pesquisa, presença de mão de obra altamente qualificada e a presença de uma eventual diversidade de serviços à economia.

O propósito foi o de ressaltar que os fatores locacionais considerados como clássicos, não deixarão de fazer parte das análises para a escolha do local de implantação da fábrica; porém, respeitando as especificidades de cada tipo de atividade industrial e não os aplicando como modelo único.

Evidências históricas demonstram a capacidade de geração de emprego nestas fábricas favorecendo predominantemente, indivíduos que trabalham na função produção com instrução educacional em nível fundamental. Outro aspecto observado é a capacidade de manutenção de empregos que esse estilo de fábrica proporciona: desde sua fase de instalação não há relato de dispensa massiva de funcionários demonstrando tendência como estabilidade de vagas de emprego e progressão de vagas ao longo do tempo. É importante ressaltar que estas vagas de emprego encontram-se concentradas para a mão de obra local, ou seja, da mesma região em que a fábrica encontra-se instalada. Ainda em relação à mão de obra, destaca-se que a exigência de instrução é extremamente baixa; fazendo a média das três empresas visitadas, conclui-se que aproximadamente $60 \%$ da mão de obra possui apenas o ensino fundamental e estão alocados na área da produção.

Finalmente, quando analisada a influência de fatores locacionais na escolha da área para a implantação da fábrica, considerando fatores como energia elétrica, transporte, preço do terreno, mercado consumidor, matéria-prima, incentivos fiscais, qualidade de vida e pesquisa/Universidade, os empresários declaram que não consideram nenhum fator em especial para a escolha do local. Porém, há que se destacar que as três fábricas foram instaladas em municípios dotados de toda infraestrutura necessária para o desenvolvimento das atividades.

Entendem-se como principais contribuições acadêmicas deste trabalho a redução da escassez de pesquisas sobre geografia econômica focadas no município de Guarapuava e Região Metropolitana de Curitiba (PR). A partir dos resultados obtidos pelo estudo, futuras pesquisas podem ser realizadas como: a) os fatores locacionais de 
ordem clássica e não clássica que influenciaram instalações de indústrias regionais; b) desenvolvimento regional de indústrias.

Como o desenvolvimento industrial constitui-se numa das principais preocupações socioeconômicas dos países semiperiféricos, entre estes o Brasil, entende-se que estudos da geografia econômica podem fornecer o aporte necessário ao crescimento de indústrias, qualificação de mão de obra, além de formação e diversificação de economias regionais reduzindo suas fragilidades.

\section{Referências}

ALONSO, William. Location Theory, In: EDEL, M; Rothenberg, J. (orgs.). Readings in Urban Economics. Londres: Macmillan Publ. Co., 1972.

ASSOCIAÇÃO BRASILEIRA DA INDÚSTRIA QUÍMICA (ABIQUIM). A indústria química. São Paulo, ABIQUIM, 2009. Disponível em: <http://www.abiquim.org.br/>. Acesso em: 05 mar. 2011.

BARRETO, Carlos E. P. A saga do petróleo: a farra do boi. São Paulo: Nobel, 2001.

BENKO, Georges. Economia, Espaço e Globalização - na aurora do século XXI. São Paulo: Hucitec, 1996.

CASTREGHINI, Olga L.; SPOSITO, Eliseu S. Indústria, ordenamento do território e transportes: a contribuição de André Fischer. São Paulo: Expressão Popular, 2008.

CHESNAIS, François. A mundialização do capital. São Paulo: Xamã, 1996.

CORRÊA, Roberto L. Região e organização espacial. São Paulo: Ática, 1987.

DICKEN, Peter. Mudança global: mapeando as novas fronteiras da economia mundial. 5. ed. Porto Alegre: Bookman, 2010.

EGLER, Claudio. A. G. As Américas: singularidades de um continente plural. In: OLIVEIRA, Márcio P. O Brasil, a América Latina e o Mundo: Especialidades Contemporâneas (I). Rio de Janeiro, Lamparina/ANPEGE, FAPERS, 2008, p. 142-147.

. Crise, mudanças globais e inserção da América do Sul na economia mundial. In: VIDEIRA, S. L. e COSTA, P. Geografia econômica: (re)leituras contemporâneas. Rio de Janeiro: Letra Capital, 2011, p. 6-15.

CASTREGHINI, Olga L.; SPOSITO, Eliseu S. Indústria, ordenamento do território e transportes: a contribuição de André Fischer. São Paulo: Expressão Popular, 2008.

FIRKOWSKI, Olga C. de F. Localização industrial e extensão urbana em Curitiba. In: MOURA, R.; FIRKOWSKI, O. (orgs.). Dinâmicas intrametropolitanas e produção do espaço na Região Metropolitana de Curitiba. Rio de Janeiro: Letra Capital, 2009, p. 157-173.

HIRST, Paul. Globalização: mito ou realidade. In: FIORI, José L. Globalização: o fato e o mito. Rio de Janeiro: UERJ, 1998. 
HOLZSCHUH, Gilson G et al. Otimização dos processos na indústria de ráfia: com enfoque no mapeamento dos processos e na geração de resíduos. In: ENCONTRO NACIONAL DE ENGENHARIA DE PRODUÇÃO, 28., 2008, Rio de Janeiro. A integração de cadeias produtivas com a abordagem da manufatura sustentável. Anais... Rio de Janeiro: ABREPO, 2008, p. 1-9.

HOTEL NEWS. Utensílio do plástico. Revista Hotel News. São Paulo, 2009. Disponível em: http://www.revistahotelnews.com.br/portal/pagina_revista_anos.php?ano=2009. Acesso em: 16 out. 2015.

IANNI, Octávio. Teorias da Globalização. 9. ed. Rio de Janeiro: Civilização Brasileira, 2001.

KON, Anita. Economia industrial. São Paulo: Nobel, 1994.

LA BLACHE, Paul V. de. Princípios de Geografia Humana. Lisboa: Cosmos, 1954.

LIMBERGER, Silvia C. A Geografia Econômica da Indústria de Embalagens Plásticas: Inovação Tecnológica e Dinâmica Espacial. Dissertação (Mestrado em Geografia). PPGG, Unioeste, Francisco Beltrão, 2010.

MANZAGOL, Claude. Lógica do espaço industrial. São Paulo: Difel, 1985.

MARTIN, Ron. Teoria econômica e geografia humana. In: GREGORY, D. et al (orgs.). Geografia Humana: sociedade, espaço e ciência social. Rio de Janeiro: Jorge Zalar Ed, 1996, p. 31-64.

MOURA, Rosa. O espaço metropolitano de Curitiba e a inserção do Paraná na divisão social do trabalho. In: MOURA, R.; FIRKOWSKI, O. (orgs.). Dinâmicas intrametropolitanas e produção do espaço na Região Metropolitana de Curitiba. Rio de Janeiro: Letra Capital, 2009, p. 131-155.

. MOURA, Rosa. Configurações territoriais no estado do Paraná - 2010. In: SIMPÓSIO PARANAENSE DE PÓS-GRADUAÇÃO E PESQUISA EM GEOGRAFIA, 6., 2012, Guarapuava. Ciência sociedade e tecnologia na perspectiva da análise geográfica. Anais ... Guarapuava: UNICENTRO, 2012, p. 20-37.

NEVES, Artur C. Sistemas de comunicação, geoeconomia e a experiência da APCNP. Sem data. Disponível em: http://portocidaderegiao.up.pt/1_edicao/conteudo/textos/ pdf2/2_Artur_Castro_Neves.pdf $>$. Acesso em: 23 mar. 2011.

NUNES, Flaviana G. A Geografia Econômica na produção científica acadêmica dos programas de pós-graduação em Geografia no Estado de São Paulo (1970-1998). Dissertação (Mestrado e Geografia). PPGG, UNESP, Presidente Prudente, 2000.

PERRONE, Otto.V. A indústria petroquímica no Brasil. Rio de Janeiro: Interciência, 2010 .

PIRES, Hindenburgo F. “Ethos” e mitos do pensamento único globalitário. Terra Livre, São Paulo, n. 16, p. 153-167, $1^{\circ}$ semestre/2001.

PORTER, Michael E. A vantagem competitiva das nações. Rio de Janeiro: Campus, 1993. 
SANTOS, Milton. Por uma Geografia Nova. São Paulo: Hucitec, 1980.

. Por uma outra globalização: do pensamento único a consciência universal. 2. ed. Rio de Janeiro: Record, 2002.

SANTOS, Milton e SILVEIRA, María L. O Brasil: território e sociedade no início do século XXI. Rio de Janeiro/São Paulo: Record, 2001.

SILVA, Armando C. O Espaço fora do lugar. São Paulo: Hucitec, 1988.

TORRES, Eduardo M. A Evolução da indústria petroquímica brasileira. Química Nova, São Paulo, vol. 20, n. especial, 1997. Disponível em: http://www.scielo.br/pdf/qn/ v20nspe/4982.pdf. Acesso em: 18 abr. 2012.

TORRES, Antonio P.; SAENZ, Alfredo. Geografia Económica. Barcelona: Ramon Sopena, 1972.

VARSANO. Ricardo. A guerra fiscal do ICMS: quem ganha e quem perde. Planejamento e Políticas Públicas, Brasília, n. 15, jun.1997, p. 3-19.

WOOLDRIDGE, Sidney W.; EAST, George. W. Espirito e Propósitos da Geografia. Rio de Janeiro: Zahar, 1967.

ELIANe Horbus

Mestre em Geografia e bacharel em Administração pela Universidade Estadual do Centro-Oeste (PR). Atualmente é professora dos cursos de graduação e especialização lato sensu da Universidade Estadual do Centro-Oeste (PR). Rua Padre Salvador, 875 - Santa Cruz - Guarapuava - PR - CEP 85015-430. E-mail: eliane.horbus@hotmail.com

Pierre Alves Costa

Doutor em História pela Universidade Federal Fluminense, mestre, licenciado e bacharel em Geografia pela Universidade Federal do Rio de Janeiro. Atualmente é professor dos cursos de graduação, especialização lato sensu e do Programa de Pós-Graduação em Geografia da Universidade Estadual do Centro-Oeste (PR). R. Simeão Camargo Varela de Sá, 03 - Vila Carli - Guarapuava - PR - CEP 85040-080.

E-mail: alvespierre75@hotmail.com 